\title{
CONCLUSION
}

\section{The invisible chain}

I

N THE FIRST PART of this study an attempt was made to consider afresh the familiar civilian experience of the Second World War in Britain with a view to assessing how well the morale of the ordinary people came through that time of trial. That it did not break was not the point at issue - no one has ever suggested it did. The issue was, simply, where on the continuum from 'low' to 'high', from 'poor' to 'good' would one, in retrospect, place the spirit and behaviour of the people during those six years.

This investigation arrived at an unequivocal conclusion: the 'negative' features emphasized by revisionist historians, although indisputably present, were not on such a scale as to invalidate the orthodox picture of a people who became actively committed to the project their leaders put before them, who cooperated with the drastic re-ordering of daily life that this entailed and who, on the whole, did so in a spirit of stoical endurance that did not exclude good humour. Undoubtedly, as contemporary observers recorded, there were times when spirits appeared generally low and when commitment and active effort seems to have slackened. But so, too, there were times when the reverse was true: it is not possible to argue that there was consistency of mood and behaviour - although one doubts the value of attempts to find significance in this. In any case, the 'lows' did not last for long and were more than outweighed by the 'highs', the mean coming, perhaps, between 'middling' and 'good'. It is clear, moreover that the great majority of the civilian population were for rather than against the war effort: those who were apathetic or obstructive were so few as to be tolerated without official resort to repression. It was possible in 1941 for people opposing the war or critical of the Government to address their views to their fellow citizens every weekend in Hyde Park without any more harassment than the largely good-humoured heckling of the onlookers. 
How does war-weariness fit into this picture? That it existed and that the Government saw it as something to be countered is undeniable. But in retrospect, it seems unimportant. What could be more natural than to long for the war to be over - as everybody surely did? Few among even the most committed would look back on the war years as 'the time of their lives' - though having taken part would be something about which many more remained intensely proud - like Ethel Singleton, who hadn't wanted to leave her job as shop assistant, but who later looked back proudly on her five years welding aircraft fuel tanks in an engineering factory: 'I think afterwards it made us feel good, you know, that

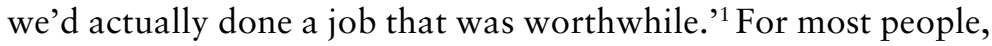
the war was at the time rather something to be got through, something they did not expect to enjoy but knew they had to take part in. War-weariness, in short, was an inseparable part of war itself. Potentially, it was dysfunctional for the war effort, but at a certain level, it was not incompatible with it. People could hate the war and resent its massive intrusion into their lives and yet carry on performing their allocated roles on the home front. For the logic of the situation was that only by such effort would come the longed-for end to the war.

The situation, however, required more than just going through the motions. In assessing how well civilians performed, one needs to bear in mind that the subjects under scrutiny here were ordinary, fallible human beings, caught up in a situation not of their choosing that at the very least turned their lives upside down and at worst threatened them and their families with violent, premature death. In these stressful circumstances, on the evidence, most people behaved well, and it is on this fact that generalization about the nation must rest, rather than on the behaviour of the minority who behaved badly. Even at critical periods in a nation's history and this was one - when people feel that the things that bind them to one another are strengthened rather than weakened, there will always be some who think and act in anti-social ways. It should come as no surprise that prejudice, selfishness and criminality continued to exist in wartime Britain, despite the obvious damage to the communal project these defects could - and did - inflict. The firing of the starting-gun in September 1939 did not - could not - transform everybody into model citizens, all equally anxious 
to demonstrate their civic and patriotic virtue. To presume, therefore, that any behaviour that deviated from the stereotype of 'the spirit of Dunkirk' is evidence of the absolute emptiness of that stereotype would be as absurd as an insistence on its absolute veracity. And more seriously, it would be a libel on the majority the great mass of ordinary people whose attitude and behaviour was more consistent with that phrase than not. A more reasonable presumption to make would be that among a nation of fortyfive million there would be a proportion to whom the very concept of 'nation' meant little or nothing, who had no respect for law or for the constituted authorities, who could not understand - let alone become part of - the notion of communal effort in a 'people's war'. The wonder is that so many of them chose to become part of that effort or at the very least did nothing to impede it.

Before the war and during its first eighteen months the ruling elites, and many others besides, had had serious doubts about the capacity of British society to hold together under the intense pressures of another total war. In the event, their pessimism proved ill-founded. The bogeys of pacifism, class antagonism, regional separatism and political dissidence receded to the point where they could effectively be disregarded. And in the meantime the Government organized the people for total war to a degree only surpassed by the Soviet Union. ${ }^{2}$ It is quite probable that many among them were largely unmoved by lofty appeals to their patriotism or were perfectly aware that the public image of how others were already behaving contained some imaginative embellishment. But they did not in consequence refuse the cooperation on which the winning of the war depended. Rather they went along with it to a degree that permitted the national project to succeed. If the traditional picture of the British people during the war is misleading, it is only in this - its assumption that most people did much more than put up with things, that selfless and enthusiastic cooperation was virtually the norm, that people like the unusually proactive Richard Brown and Nella Last were typical. This is not tenable. It seems, therefore, that there are grounds for reviewing the traditional picture, to acknowledge that it is in need of some modification - as, perhaps, unduly influenced by the propaganda myth constructed at the time. The evidence however, does not support its total rejection as merely the product of myth-making. In its 
broad contours it remains a largely truthful representation of how things were in the home front war.

To re-assert the basic veracity of the received picture of the British people in the war is not difficult: the evidence is clear enough. But to explain it, the historian is obliged to move onto altogether less certain terrain - the inside of people's minds. The picture here is constructed - ultimately, can only be constructed - from the glimpses afforded into why people felt and acted as they did that survives in the incomplete patchwork record of contemporary voices, some specifically attempting to set down the motivation of others, others speaking only for themselves. What emerges is a predictably complex picture in which, for every individual, morale was created out of an interplay between the public and the private, the sense of being part of a community and the private need to meet the war on one's own terms.

Much official effort went into trying to win and retain the people's hearts and minds for the task in hand, to get them to think and behave 'correctly'. The Government did not take for granted that in war the people would acquire a heightened sense of national identity and would have confidence in victory, even when these characteristics manifested themselves at quite an early stage. How much, if any, of the official effort was actually necessary is difficult, probably impossible, to determine. On the other hand, people appreciated the steps taken by the Government to protect them and to improve the material conditions of their lives, albeit without having any illusions as to why it did so. None of these steps was a waste of effort. The real value of these measures lay in making a potentially unbearable situation bearable, in providing, as it were, a culture medium in which good behaviour would flourish. While they may not, therefore, have been absolutely essential to the mental buoyancy of the civilian body nor to its generally supportive attitude and cooperative behaviour, they nevertheless form part of the wider framework of explanation. Given the generally low regard in which parties and politicians were traditionally held - the war did not overnight lead people to abandon the mildly cynical attitude towards politicians that was the cultural norm in mid-twentieth century Britain - it is notable that during the war years, when politicians meddled in people's lives as never before, there was no 
sense that the country was badly governed by men who did not deserve the backing of the citizens. Most people felt that the wartime regime, for all its flaws, was basically fair and that the Government was as responsive to welfare needs as the constraining economic situation allowed. This was the context in which austerity - and its creator, the Lord Privy Seal, Sir Stafford Cripps - was actually popular and in which rationing and even the conscription of women were welcomed. ${ }^{3}$

Since things did not fall apart, since the more optimistic scenario of civilian 'performance' was in fact realized, one is tempted to wonder whether it would have happened thus, anyway, regardless of the carefully calculated policies of the authorities. Seen from the official standpoint, however, the depth of the well of popular goodwill was unknowable. One can only speculate upon the consequences had the leaders relied only on appeals to national sentiment and neglected the welfare of the people. For its part, the Government could with reason feel quietly gratified when intelligence was received in March 1943 that the failure of the Italian authorities adequately to protect and care for civilian workers in the northern cities, who at that time were being subjected to heavy RAF bombing raids, had seriously undermined morale and stoked the fires of anti-war and anti-Mussolini sentiment. It was the avoidance of just such negative consequences of total war that provided the rationale for its own policies of care and protection on the home front.

Mostly, when asked, people did not see themselves as much persuaded - nor needing to be persuaded - by propaganda or other inducements to cooperate. There is quite strong evidence that the people knew very well their performance was being watched and worried over, and that they rather resented the implication that they were poor-spirited or could not be trusted to know just what was happening in the war - nor do the proper thing when they did know. They cooperated because they understood it was necessary. Churchill was right, therefore, when he instinctively felt that his resolute and defiant stance in 1940 was what most people wanted him to adopt, because that was how they felt, too; and he was right in believing, during the long haul that followed, that they might grumble continuously, but underneath they were as determined as he to see the war through to a victorious conclusion. By all accounts he paid little attention to his standing in opinion polls, but if 
he had, he would surely have been confirmed in his conviction that his instincts about the collective will were correct. He offered them a single, uncompromising course of action, and they rallied behind him and continued to have confidence in him through the long wait for the turn of the military tide. When Churchill spoke of Britain standing between civilization and barbarism, the average citizen took this to mean that the British way of life was threatened by an alien force; and, for all its faults, that way of life was preferable to Nazism and worth fighting to retain. At its most basic this is what patriotic feeling consisted of - an attachment to familiar ways of doing things, rooted in a familiar place. In the autumn of 1941 Mass-Observation asked its observers to set down 'What Britain Means to You'. The replies, though hardly constituting a representative sample of the population, nevertheless provide a revealing insight into some of the national attributes with which people identified at this point in the war. In contrast to the high-flown stuff of leaders' speeches and heroic films, the content was altogether more prosaic, banal even. Above all things came the countryside - the variety of the orderly farms and picturesque villages, the rocky coves, the gentle hills and rugged uplands. Then, in order, came politics, people and home, and again the emphasis was on how things worked, looked and felt, rather than on abstract ideas about constitutional rights and freedoms. Thus we read of the 'easy tolerance and good humour' of the British, and 'the feeling that in Britain you need not feel afraid'. ${ }^{4}$ Flag-waving patriotism was notable by its absence. As Tom Harrisson observed in an article based on the survey that he wrote for the World Review, when British people think about their country they bring to mind 'tangible and visible things they know and individual people whose characteristics they have known and can trust and feel affection for ... this is the land [they] were brought up on, that is the beginning and end of it'.

This 'gut patriotism' was already aroused a year or more before Mass-Observation's survey. 'In those weeks in May and June', wrote Margery Allingham in the autumn of 1940, 'I think ninety-nine percent of English folk, country and town, found their souls ... They'd rather die when it came to it than be bossed about by a Nazi ... If we are not free tomorrow, we shall not be happy tomorrow.' The delusion that the British way of life could survive without a fight - without victory over Nazism - was evident to most by the 
time of the fall of France in June 1940 and quite dispelled by the deadly dual of the Battle of Britain and the murderous experience of the Blitz in the months that followed. 'We are carrying on because we have got to', wrote a 20-year-old Mass-Observation diarist during the bombing in Manchester in December 1940 - a plain-spoken recognition that everyone was in the same boat and there were no real alternatives to the course that Churchill had set. ${ }^{7}$ But to interpret this as evidence that cooperation resulted merely from a sense of the futility of resistance would be to underestimate the strength of the visceral emotions the threatening situation aroused. The support was unconditional, requiring no promises, no prior deal. And significantly, it was given before leaders and led went together through the unifying cauldron of the Blitz.

At the start of that experience it seemed to the inhabitants of the East End that they alone were to be the victims. This apprehension was short-lived, however, fading away as the bombing extended to other parts of the capital and then to other cities, and the same sense of being 'all in it together' was reinforced: suffering shared was suffering endured. There is even some evidence that the bombing actually strengthened morale and the determination to survive and rebuild - evidence matched, incidentally, by the German experience under Allied bombing. ${ }^{8}$ This was how the young diarist Colin Perry saw it after viewing the spirited way the people of bomb-hit Morden 'carried on': 'There will never be any breaking of the British morale; we do not get jittery, only harder, grimmer and determined the more.' Angus Calder believed that the decline in the suicide rate during the war derived from the heightened sense it brought of being part of a community, of having a common experience and a common goal, which gave 'a proud and even gay motive for existence'. ${ }^{10}$ Contemporary observers often acknowledged the existence of disharmonies in the war effort. But they invariably discounted their significance alongside the broad picture. As Margery Allingham, in her small rural community, put it: 'It was all talk, and we are fighting to say what we like. ${ }^{\prime 1}$

No one was more surprised by this than George Orwell, who believed that the bitterly class-ridden society that Britain was in the 1930s could hardly pull itself together to fight a war, let alone win one. To his credit he admitted his error when he was proved wrong. In December 1940 he wrote: 'England is the most class-ridden 
country under the sun ... But in any calculation about it one has got to take into account its emotional unity, the tendency of nearly all its inhabitants to feel alike and act together in moments of supreme crisis ... The nation is bound together by an invisible chain ... Patriotism is finally stronger than class-hatred. ${ }^{12}$ In this the Coalition Government that Churchill formed was itself powerfully symbolic: when erstwhile political adversaries had sunk their differences and became part of a single team, their call for the people to do likewise was bound to succeed. But it did not matter that in standing together the British people had various, even opposing, notions of what they were fighting for - as various as the things about Britain that were important to them. ${ }^{13}$ The point was that, for whatever reason, they had common ground in the belief that compromise with the enemy was unthinkable, that there was no alternative to seeing the struggle through and that this was best achieved by acting together. As the war proceeded, the accumulated shared experience of life on the home front, together with the public discourse about what it meant to be British, served to reinforce people's sense of being part of a national community.

The instinctive closing of ranks that Orwell witnessed helps to explain the remarkable upsurge of morale in June 1940 and the almost enthusiastic acceptance by the people of the extraordinary measures and demands the Government announced. Mollie PanterDownes was already anticipating this at the end of May: 'They are ready emotionally for the most drastic measures $\mathrm{Mr}$ Churchill may choose to take', she wrote. ${ }^{14}$ When the official historians came to reflect on this time they confirmed those contemporary impressions: [The British people] 'now passionately attached themselves to the war. This was the great transforming fact, the motive power of all subsequent achievement. ${ }^{15}$ Of great symbolic importance in all this was Churchill's decision to reject 'Black Move' - the plan made before the war to shift the Government itself out of London when the bombing began. By deciding to stay, Churchill - like the King, who also stayed, to the lasting esteem of the House of Windsor made yet more solid the support of the ordinary citizen for his stand and for his programme of action.

While it is true that the Government gave itself enforcement powers that in theory could have enabled it to get its way at any point in the war, in practice it was not the fear of compulsion that 
led the mass of the people to cooperate. In fact, when a matter of principle was involved, particular groups were prepared to depart from their cooperative stance and stand firm against the Government, as in the Betteshanger miners' strike in 1941-42. In this instance the Government ultimately retreated from compulsion and the miners achieved their objective. ${ }^{16}$ The argument which is sometimes heard, that the people did as they were told in the Second World War because they were cowed into acquiescence by the threat of vigorous official action against resisters, is not easily sustained in the face of such evidence. In practice the Government normally judged strong-arm tactics to be counter-productive, literally - striking miners produced no coal. In any case, the reality was that most workers never contemplated striking. More typical was Doris Scott, who was twice evacuated from London's dockland with her two young children and who worked part-time at an engineering firm in Henley, making aeroplane parts: 'Oh well, Churchill was exhorting everyone to do their bit. Oh! I was thrilled! I thought, my God, I'm helping in the war effort, and I was so thrilled to be taken on and given my own lathe to work on - oh! I felt so important and happy about it!' Or Molly Weir, who also volunteered for war work: 'I was directed into this factory making what they called fragmentation bombs. I was proud to be there for I was very patriotic and never had any doubt that we'd win. ${ }^{17}$ Or, more mildly, Denise Aylmer-Moore, who went to train army horses: 'Did I feel patriotic at eighteen and a half? I don't know. I was glad I was doing war work, and I certainly would have gone on to the land if I hadn't been at the Remount Depot. ${ }^{18}$

The positive response to the Government's call for an increase in the national effort on all fronts owed much to a mental context in which the possibility of defeat was denied. Constantine Fitzgibbon believed spirits were so high in Britain in May-June 1940 because the British people 'had no first-hand knowledge of defeat and, being a remarkably unimaginative people, have never been able to conceive of it as more than a theoretical possibility'. ${ }^{19}$ Looking back from the comparative safety - in Ipswich, at least - of September 1944, Richard Brown reflected on the range of mental qualities the war had put to the test and concluded: 'Patience, I think, has been most exercised but I can't say that fear, fear of the outcome, I mean, was ever experienced except for a few days in the Dunkirk period 
perhaps. ${ }^{20}$ And in the long retrospect of 2000, some women recalled for a radio programme that even at the height of the Emergency, they were certain of ultimate victory: 'Everyone knew that we'd got our backs to the wall, but we had this confidence that somewhere, something would happen. It would take a long time. But it was all going to be all right in the end'; 'Nobody said: "Oh, let's give in", or anything like that. It just made us all the more determined to carry on'; 'It never occurred to me - it never occurred to any of my family - that we were going to lose that war. And that sort of kept us going, you know? 21

This conviction was buttressed by the knowledge, assiduously supplied by the press and radio, that offensive operations were being conducted against the enemy. In the early years this meant exclusively the bombing of Germany. There is no doubt that merely knowing that this was happening was important to many people's whole outlook. In the dreadful first week of the Blitz, the US military attaché, Raymond E. Lee visited Whitechapel and recorded in his diary: 'People were evacuating, others were grubbing about in the wreckage to salvage what they could. But no one was complaining. One workman said, "All we want to know is whether we are bombing Berlin. If they are getting all or more than we are, we can stick it". ${ }^{22}$ A month later, Churchill, also visiting the East End, heard the same refrain on every side: 'We can take it', but also 'Give it 'em back.'23 Vere Hodgson, who stayed in London throughout the Blitz, recorded seeing the bombers going off to bomb the enemy in August 1943: 'It is a fine sight, and gives us a feeling of strength', and later, 'As I lay in bed ... I heard the deep purr of our bombers winging their way to Hamburg ... This is a comfortable feeling. ${ }^{24}$ Such an effect on morale was undoubtedly in the Government's mind when it began the strategic bombing campaign against Germany. In the 1940-42 period, for most of which Britain stood alone, bombing was arguably less a strategy for winning the war than a device to sustain morale at home. The 1000-bomber raid on Cologne on 30 May 1942, for instance, while undoubtedly successful in purely military terms, also helped to offset the moralesapping effect of the 'Baedeker' raids, which were being made at this time on some of England's historic towns. ${ }^{25}$

It was perhaps fortunate that confidence in ultimate victory was subjected to its most testing time so early in the war. For after 1940-41, 
when nothing could seem worse than what was then experienced, the home front was able to be sustained, increasingly, by good news on the military fronts, balancing the war-weariness that was the inevitable effect of the sheer length of the war. And crucially, the long haul, dreary and burdensome though it was, was free of the undertow of fear that, for all the brave words, lurked in the minds of many in 1940-41 - that the war might be lost. A glimpse of the working of this factor can be seen in an entry from Mollie PanterDownes's journal during the euphoria over the victory at El Alamein and the success of Operation Torch in Tunisia: 'The British success effectually knocked on the head the dangerous notion that German arms and leadership are infallible ... Today, though sensible Britons think there's certain to be plenty of grimness ahead, for the first time they believe that sober reasons for hope are at last in sight. ${ }^{26}$ The stimulus of good news upon the war effort is widely attested to - when J. B. Priestley wrote his novel Daylight on Saturday, set in an aircraft factory, there was authenticity in his representation of the workers increasing their efforts and improving the factory's production figures on hearing the news of El Alamein. ${ }^{27}$

At several points in this study allusion has been made to the widely-shared sense that the war was a time of trial not just for the state and its institutions but for individuals in their own setting of family, workplace and local community. At the level of the local community it is evident - once the Phoney War gave way to the real war, at least - that the test became a matter of local pride, especially in relation to how the community bore up when the bombing came. How the people of London endured the Blitz with bravery and good humour was quickly established - doubtless in part through instant myth-making by propagandists - as a sort of yardstick against which every town that was subsequently bombed felt it was being measured or, indeed, measured itself. Mass-Observation judged that the stoicism it saw in the people of Coventry, ten days after the terrible raid of November 1940, came as much as anything from a shared feeling of pride - no community had suffered as badly as they and yet they were 'up and doing' in no time at all. ${ }^{28}$ This ingredient of 'carrying on' was to be found practically everywhere, as if each city, as its turn to be bombed came, had a mental picture of how to behave, constructed from the newsreels and documentary films about previously raided 
cities. The sense of being on trial, of being under a national spotlight, typically extended through the entire community, from the councillors and paid officials who insisted on retaining local control of operations, to the numberless individuals who acted selflessly and sometimes heroically. This is only partly explained by the attempt to live up to the officially inspired media myths that were being created about the sturdy stoicism of the British. More important was society's moral pressure on the citizen to conform to the special norms of war, the norms that banished the very idea of defeatism. As Harrisson put it: 'In war ... the sanctions on staying steady are stronger in terms of respectability, good citizenship, the due observance of familiar and wider obligations. ${ }^{29}$ Thus were the primitive instincts of self-preservation and self-interest - themselves heightened in times of danger and disorder - frequently overridden by the group norms of the tribe at war.

The enhanced sense of being part of a group can also be attributed, in part, to the special institutional structures of communal action that the war situation itself created. During these years positions of responsibility - in the ARP, the AFS, the Home Guard, the WVS, and the like - were held by many millions of adults who in the normal course of events would never have expected, or been expected, to have such roles. These positions usually entailed the absorption of knowledge and procedures and the acquisition of skills, during the course of which the individual became more fully a part of the structure of the local community. Citizenship, in short, had for a significant proportion of the civilian body a concrete referent in the performance of these roles. It ought also to be remembered that the years of war, when everyone had a job to do, followed a long period of mass unemployment, when millions experienced demoralization and loss of self-respect. The war offered opportunities for relieving these feelings. Such a development was intrinsically favourable to the steadiness of the community first under fire and then through the long years of regimentation and restriction. It also, naturally, had a political dimension, creating sources of potential conflict between and within the new groupings and between them and existing institutions. But far outweighing the pulling and hauling that inevitably accompanied the operation of the new arrangements was the strong sense of mutual dependence that stemmed from the basic reality of the 
situation: at this time the whole community, national and local, was threatened - everyone was equally a potential victim. This time, war was not something that only happened far away. The fact that it was brought literally into everyone's path made it impossible to put it out of mind for long and impossible not to feel more intensely part of a larger community than oneself and one's intimates. The contrast between the relatively weak sense of community that characterized the period of the Phoney War and the transformed mentality that emerged after the trauma of the bombs is indicative: war imagined was replaced by war experienced. Mass-Observation recorded this process in microcosm when it looked at the situation in Bristol in March 1941 and discovered a new social sub-stratum in the institution of fire-watching. In some districts the fire-watchers got together in one another's houses in turns to play cards; some met as a group in particular pubs. Since the members were typically drawn from all classes, Mass-Observation thought the functional activity that had brought them together was probably serving to break down class barriers. This was Richard Brown's own experience in the Home Guard. Writing at a much later point in the war - May 1944 - he reflected on one of the unexpected outcomes of taking part: 'There is a camaraderie in the [HG] platoon which one doesn't get anywhere in peace life. It's a sort of mass friendship I would never have experienced in peacetime. ${ }^{30}$ For him and his colleagues, at least, the spirit of the Blitz seemed as strong after nearly five years of war as it had been in 1940 .

Perhaps it was the existence of such feelings that encouraged people to hope the war experience would foster the construction of a better society after victory was won and to reject the jibe of 'wishful thinking'. Illusion or not, the salience of reconstruction talk from 1941, the laying of some of its building blocks in 194344 and the ubiquity of the 'Never Again' mentality were powerful counters to the inherent tendency of extended war to depress the human spirit. Since without hope there is no energy and no commitment, the performance of the British in this regard for several years beyond the point where defeat threatened, suggests a nation that looked to a better future. In the several years it took to defeat the Axis powers, the promise of that future gave added purpose to the task. 
Heightened sense of national identity, participation, shared dangers, the hope of a better future - all these created a favourable context for the maintenance of civilian morale. But no scrutiny of the contemporary social record and the retrospective recall of those who lived through the war years can fail to notice that, strong though the communitarian spirit was, for many people - probably most people - an absolutely essential ingredient of personal morale was having some entirely self-centred means of mental escape from the war. The precondition of being able to do this was to have become accustomed to the nature of war - including the risk of being hit by bombs. It is evident that the ability to do this was so common as to be counted normal, even allowing for the fact that the really fearful had mostly left the danger areas at an early stage, leaving behind only the mentally more resilient majority. ${ }^{31}$ Thereafter, people increasingly appear to have simply adjusted to the changed 'normality', and settled into its special routines. Vere Hodgson gave several instances of this remarkable adaptation. She recorded a tale told her by a woman with whom she had got into conversation in a café: 'She was having luncheon in Oxford St. Suddenly a terrific wonk shook the place; all the cups and saucers danced and rattled about the table. The man opposite her said calmly: "That was a bomb, wasn't it?" She replied: "I'm sure it was". And they all continued to eat their meal.' Taking a lunchtime walk in Kensington Gardens, Vere Hodgson found that despite the fact that part of the park was roped off because of an unexploded bomb, people still sat in seats alongside. 'People were peacefully sitting in those seats, and some had even penetrated the barrier, and were happily basking on the grass in the sunshine. Shows how indifferent we have got. ${ }^{32}$ Reading her journal one also notices that she herself unconsciously slipped into referring to the raids as if reporting on the weather: 'Very blitzy tonight'. The nonchalance of individuals was not exceptional. It was encountered by Mass-Observation whenever it studied a community that was experiencing air raids. In Southampton, for instance, one month after the raids that gutted the town centre, it noticed that people were taking little or no notice of sirens unless they were accompanied by the noise of bombs or guns. ${ }^{33}$

Getting away from the war for most people meant defying the constraints of dark streets, fewer buses and trams and engaging in 
social activity of some kind. In Sheffield, J. L. Hodson came across 'fellowship groups' - informal gatherings in people's homes to play music, read plays, discuss art and religion or work at some handicraft. ${ }^{34}$ For young people a much more typical getaway was dancing. The war years witnessed a great increase in dancing; regular dance halls extended the dancing week and in every place where the war threw young people together - hostels, army camps, air bases - dances were organized for the growing throng of enthusiasts for the craze. It was again in bomb-shattered Southampton although in this it was not unusual - that Mass-Observation found the otherwise dead and desolate centre enlivened by youthful crowds flocking to dances at the Guildhall and Banister Hall. ${ }^{35}$ The dancing craze was given an extra stimulus when bases were set up to house the thousands of US forces that arrived in Britain for the strategic bombing offensive against Germany and for the build-up to Operation Overlord. May Reeves recalled their enormous impact on her and her friends in Wigton: 'For teenagers it was heaven. We just didn't realise there was a war on. All we were doing was having a good time. I had brothers away fighting; naturally, I worried about them, but we were having such a good time that you didn't realise that they were away actually fighting in the war. We were too busy enjoying ourselves all round the place. Dances all round. ${ }^{36}$ Was this ability to banish troublesome thoughts about the war simply the callousness of youth? More probably it reflected a psychological need - one that everyone shared - to do precisely this. And it is clear that, in one way or another, everyone did. For many it came in the form of a visit to the cinema or theatre; Vere Hodgson braved the bombs to do so: 'Went to the theatre ... Dear Brutus ... Most enjoyable - felt we had just been let out of prison. ${ }^{37}$ For others it was the less structured mental escape of reading or music. The increase in the sales of poetry books and the appearance of several new poetry magazines was one of the more remarkable aspects of a general upsurge in reading. As for music, Mollie PanterDownes was unequivocal: 'we need the rectifying influence of music, which can stand for an immutable order of being, unshaken by the shocks of politics'. ${ }^{38}$ And The Times recorded people satisfying that need in the National Gallery's lunchtime concerts: 'People hurry out into Trafalgar Square, shouldering their gas masks and looking all the better for having been lifted for an hour to a plane where 
boredom and fear seem irrelevant. ${ }^{39}$ That was for the few; most people relied for musical (and other) escape on the BBC, that taken for granted but comforting background to millions of lives through the long years of war.

But what is striking about the 'escaping' phenomenon is that it could take a great variety of forms - there was no formula that served everyone equally well. It might consist of no more than finding space for a long-established pastime. For the little group of men with whom the writer H. E. Bates spent many hours on a Kentish riverbank it was plain what worked for them. As one of them put it: 'If it wasn't for the fishing, we should all go bloody crazy!'40 Retaining one's sanity was, indeed, the whole raison d'être of such apparently profligate use of time, when victory supposedly depended on maximizing the nation's labour potential. Human beings caught up in the whirlwind of that mobilization and its side-effects instinctively found their own special ways of coping with it: ultimately, in this time of community, one had to make the personal adjustment that enabled one as a unique individual to carry on. This surely comes close to what Tom Harrisson meant when he spoke of morale 'going on at another level'. ${ }^{41}$

Everyone who lived through this time would readily have understood this idea that there was more to morale than what the Government and its agents said or did. And yet there was always an awareness that the process of individual adjustment was not wholly divorced from - indeed, needed as its complement - what others in the wider community were feeling and doing. And most felt to some degree assisted in it by the measures the leaders of that community - the Government - took to create an environment helpful to adjustment and commitment, one that afforded protection and reassurance and which eased the burdens of war, even down to releasing the resources that enabled new poems to be read and new feature films to be seen. As it was perceived so it was in reality. In the end it was this combination of 'public' and 'private' factors, operating within a mental framework of common identity and shared destiny - the 'invisible chain' - that determined civilian morale. Uncoordinated and lacking comprehensiveness or even consistency, it was nevertheless a combination that worked well enough for that contradictory and perplexing entity, the British nation, to survive with honours its most threatening and taxing challenge. 


\section{Notes}

1 P. Summerfield, Reconstructing Women's Wartime Lives (Manchester University Press, 1998), p. 96.

2 In a comparison of resource mobilization in Britain, Germany, the USA and the USSR, M. Harrison concluded that Britain had 45.3 per cent of its working population in war-related work, alongside the USA's 35.4 per cent and Germany's 37.6 per cent and the USSR's 54 per cent. See M. Harrison, 'Resource Mobilization for World War II: the USA, UK. USSR, and Germany', The Economic History Review, vol. 41, no. 2, 1988, p. 185.

3 A. Calder, The People's War: Britain 1939-45 (Jonathan Cape, 1969), pp. 275-82.

4 M-O, File Reports 878 September 1941, and 904, October 1941.

5 T. Harrisson, 'What Britain Means to Me', M-O, File Report 904.

6 M. Allingham, The Oaken Heart: the Story of an English Village at War (Sarsen Publishing, [1941], 1987), p. 220.

7 T. Harrisson, Living Through the Blitz (Collins, 1976), p. 249.

8 See, for example, C. Bielenberg, The Past is Myself (Corgi, 1984), p. 127.

9 C. Perry, Boy in the Blitz, (Colin A. Perry, 1972), p. 69.

10 Calder, The People's War, p. 357.

11 Allingham, The Oaken Heart, pp. 369-71.

12 S. Orwell and I. Angus (eds), The Collected Essays, Journalism and Letters of George Orwell, vol. 2, (Penguin,1970), pp. 87, 118.

13 John Baxendale has made a compelling case for the heterogeneous nature of feelings of national identity in the war years. See J. Baxendale, "'You and IAll of Us Ordinary People": Renegotiating "Britishness” in Wartime', in N. Hayes and J. Hill (eds), Millions Like Us? British Culture and the Second World War (Liverpool University Press, 1999), pp. 295-322.

14 M. Panter-Downes, London War Notes 1939-1945 (Longman, 1972), p. 61.

15 W. Hancock and M. Gowing, The British War Economy (HMSO, 1949), p. 209.

16 The miners at Betteshanger had gone on strike over pay. Although the three leaders of their local trade union branch were jailed and all the men were fined, the strike continued until settled in the miners' favour nineteen days later. Their victory was reinforced by the release of the imprisoned officials soon after.

17 Doris Scott, recorded interview, Imperial War Museum audiotape, The Home Front 1939-1945; Molly Weir, in M. Nicholson (ed.), What Did You Do in the War, Mummy? (Chatto \& Windus, 1995), p. 139.

18 Ibid., p. 101.

19 C. Fitzgibbon, The Blitz (Macdonald, 1957), p. 37.

20 H. Millgate (ed.), Mr Brown's War: a Diary of the Second World War (Sutton, 1998), p. 228.

21 'The Summer of 1940', BBC Radio 2 programme, August 2000.

22 J. Leutze (ed.), The London Observer: The Journal of General Raymond E. Lee 1940-41 (Hutchinson, 1972), p. 51.

23 T. H. O’Brien, Civil Defence (HMSO, 1955), p. 398. 
24 V. Hodgson, Few Eggs and No Oranges (Denis Dobson, 1976), pp. 329, 331.

25 See N. Frankland, Bomber Offensive: the Devastation of Europe (Purnell, 1969), p. 49.

26 Panter-Downes, London War Notes, pp. 249-50.

27 J. B. Priestley, Daylight on Saturday (Heinemann, 1943), p. 286.

28 Harrisson, Living Through the Blitz, p. 137; M-O, File Report 495.

29 Harrisson, Living Through the Blitz, p. 94.

30 Millgate (ed.), Mr Brown's War, p. 218.

31 Tom Harrisson calculated that by October 1940 something like a quarter of London's population was gone from the capital. See Harrisson, Living Through the Blitz, p. 96.

32 Hodgson, Few Eggs and No Oranges, pp. 112, 153.

33 M-O, File Report 603.

34 J. L. Hodson, The Land and the Sea (Gollancz, 1945), p. 254.

35 M-O, File Report 603.

36 May Reeves (née Charters). Cited in M. Bragg, Speak for England (Secker \& Warburg, 1976), pp. 265-6.

37 Hodgson, Few Eggs and No Oranges, p. 152.

38 Panter-Downes, London War Notes, 24 November 1939, p. 27.

39 The Times, 24 November 1939.

40 H. E. Bates, In the Heart of the Country (Robinson, 1985), p. 123. First published in Country Life, 1942.

41 See the final paragraph of Chapter 4. 
Robert Mackay - 9781526137425 Downloaded from manchesterhive.com at 04/26/2023 01:28:37AM 